\title{
Geochemical appraisal of fluoride-laden groundwater in Suri I and II blocks, Birbhum district, West Bengal
}

\author{
Shreya $\operatorname{Das}^{1} \cdot$ S. K. Nag ${ }^{1}$
}

Received: 17 November 2015/ Accepted: 21 July 2016/Published online: 2 August 2016

(C) The Author(s) 2016. This article is published with open access at Springerlink.com

\begin{abstract}
The present study has been carried out covering two blocks-Suri I and II in Birbhum district, West Bengal, India. The evaluation focuses on occurrence, distribution and geochemistry in 26 water samples collected from borewells spread across the entire study area homogeneously. Quantitative chemical analysis of groundwater samples collected from the present study area has shown that samples from two locations-Gangta and Dhalla contain fluoride greater than the permissible limit prescribed by WHO during both post-monsoon and pre-monsoon sampling sessions. Significant factor controlling geochemistry of groundwater has been identified to be rock-water interaction processes during both sampling sessions based on the results of Gibb's diagrams. Geochemical modeling studies have revealed that fluorite $\left(\mathrm{CaF}_{2}\right)$ is, indeed, present as a significant fluoride-bearing mineral in the groundwaters of this study area. Calcite or $\mathrm{CaCO}_{3}$ is one of the most common minerals with which fluorite remains associated, and saturation index calculations have revealed that the calcite-fluorite geochemistry is the dominant factor controlling fluoride concentration in this area during both post- and pre-monsoon. High fluoride waters have also been found to be of 'bicarbonate' type showing increase of sodium in water with decrease of calcium.
\end{abstract}

Keywords Groundwater · Fluoride · Geochemistry · Suri

S. K. Nag

SisirKNag@gmail.com

1 Department of Geological Sciences, Jadavpur University, Kolkata 700032, India

\section{Introduction}

Groundwater contamination resulting from the presence of high fluoride in groundwater has been encountered in many parts of the world (Brunt et al. 2004; Edmunds and Smedley 2006). High fluoride in groundwater is usually associated with arid climate conditions where water movement is slow. All over the world, more than 260 million people consume water containing more than $1.0 \mathrm{mg} / \mathrm{l}$ of fluoride, and the majority of these people are based in tropical countries experiencing arid to humid climate type. The World Health Organization has set the permissible limit of fluoride in drinking water at $1.5 \mathrm{mg} / \mathrm{l}$ (WHO 2011). Though presence of limited amount of fluoride $(0.6-1.0 \mathrm{mg} / \mathrm{l})$ in drinking water is necessary to prevent dental caries, excess fluoride consumption ironically leads to fluorosis, which is of two types: dental and skeletal (Choubisa et al. 1996; IPCS 2002; Yadav et al. 2009). Fluorosis, which is the major irreparable physiological damage caused due to excess consumption of fluoride, is spreading at a slow but steady rate (Agarwal et al. 1997; Brindha and Elango 2011; Hussain et al. 2011). Fluorosis is prevalent in some parts of central and western China and caused not only by drinking fluoride in groundwater but also by breathing airborne fluoride released from the burning of fluoride-laden coal. Worldwide, such instances of industrial fluorosis are on the rise (UNICEF 1999a). One of the best-known high fluoride belts on land extends along the East African Rift from Eritrea to Malawi, and there is another belt from Turkey through Iraq, Iran, Afghanistan, India, northern Thailand and China (WHO 2006). Undesirable amount of fluoride in groundwater, i.e., greater than $1.5 \mathrm{mg} / \mathrm{l}$ was first reported in the Nellore district in Andhra Pradesh, India, in the year 1937 (Short et al. 1937). In 1991, groundwater in 13 states of India, including West Bengal, was reported to contain greater than $1.5 \mathrm{mg} / \mathrm{l}$ 
of fluoride (Mangla 1991). By 1999, including West Bengal the number of states reported with endemic fluorosis went up to 17 in India (UNICEF 1999b). All of these states have reportedly encountered endemic fluorosis at various levels (FRRDF 1999; Yadav et al. 1999, Yadav and Lata 2004). Fluoride concentration is also correlated with depth of the water table and increases with increase in depth of the corresponding aquifer (Brunt et al. 2004). In this chapter, the occurrence, distribution, origin and geochemistry of fluoride in groundwater have been discussed.

Fluoride occurs both in igneous and metamorphic rocks, and the minerals which are part of natural formations and bedrocks of aquifers and contain fluoride are amphiboles, micas, certain clays (illite, chlorite), villiaumite (NaF) (Boyle and Chagnon 1995; Apambire et al. 1997), fluorite $\left(\mathrm{CaF}_{2}\right)$, fluorapatite, biotite, muscovite $\left(\mathrm{KAl}_{2}\left(\mathrm{AlSi}_{3} \mathrm{O}_{10}\right)(-\right.$ $\mathrm{F}, \mathrm{OH})_{2}$ ), etc. During weathering of these formations and circulation of water around these rocks and soils, fluoride can leach out and dissolve into groundwater and thermal gases. Thus, fluoride content of groundwater varies greatly depending on the geological settings and type of rocks (Brunt et al. 2004). Thus, the bedrock mineralogy of aquifers and host rocks most abundant in fluoride minerals can be attributed to be major sources of geogenic fluoride contamination in groundwater (Chae et al. 2007). Hydrolysis, dissolution and dissociation reactions that happen over time in natural water systems lead to ion exchange processes which release the fluoride ion into groundwater. Alkaline water systems and minerals containing higher amounts of bicarbonate $\left(\mathrm{HCO}_{3}^{-}\right)$and hydroxyl $\left(\mathrm{OH}^{-}\right)$ions in solution or in solid phase result in presence of free fluoride in water. The fluoride ion is similar to the hydroxyl ion in terms of ionic size and chemical properties and, hence, can exchange places during displacement reactions in high $\mathrm{pH}$ conditions. Besides the natural factors, certain anthropogenic sources which contribute to fluoride in groundwater are mainly the agriculture industry using high doses of phosphatic fertilizers, clay industries and industries using coal, for e.g., thermal power plants and brick kilns.

\section{Study area}

The present research work has been carried out in two blocks of the Birbhum District-Suri I and Suri II. Suri is the district headquarter of the Birbhum district, and its geographic location is approximately between longitudes $87^{\circ} 25^{\prime} \mathrm{E}-87^{\circ} 40^{\prime} \mathrm{E}$ and latitudes $23^{\circ} 45^{\prime} \mathrm{N}-24^{\circ} 00^{\prime} \mathrm{N}$. The climate of the area during summer is hot and dry with temperatures soaring to $40^{\circ} \mathrm{C}$ and above, whereas in winter, temperatures fall to $10{ }^{\circ} \mathrm{C}$ or below. The district, on an overall, experiences moderate to high rainfall during the monsoon season. The study area has two main rivers running across its breadth-river Kushkarani in the extreme north and river Bakreshwar in the central and southern parts. River Mayurakshi runs through the Md.Bazaar block and falls just outside the study area lining its northern boundary. The study area largely comprises alternating layers of sand and clay, which are soft sediments and part of the Ganga-Kosi formation. Granite gneisses which are hard and foliated type rocks belonging to the Chotanagpur gneissic complex constitute the northwestern part of the study area. Hard clays dominate specific parts of the block in the eastern parts of Suri, whereas lateritic soils are scattered mainly in the upper parts of Suri. Figure 1 represents the study area map presenting the geology of the area and the sampling location points. Figure 2 presents the distribution of fluoride in groundwater on three levelsglobal, national and state level.

\section{Methodology}

For the present study, two sets of 26 borewell water samples have been collected in consecutive post-monsoon and pre-monsoon sessions. For analyzing the samples, quantitative chemical analysis methods were adopted in the laboratory. Fluoride ion concentration in water was determined using the ion-selective electrode setup (APHA 1995). Identification of dominant mineral phases and calculation of their saturation indices have been carried out using the USGS geochemical model PHREEQC 3.0.3. Simulations have been carried out on two sets of data for each sampling session-one where highest value of fluoride has been recorded and another where the lowest value of fluoride has been recorded. The rest of the interpretations have been made using hydrogeochemical facies in form of the Piper's diagram (Piper 1944).

\section{Results and discussions}

Presence of fluoride in groundwater of a particular area as previously mentioned depends majorly on the geological setting and lithology of the study area. The spatial and temporal distribution pattern of fluoride ion in groundwater of the study area has been presented in Fig. 3a (post-monsoon), b (pre-monsoon). A part in the study area where high fluoride has been reported is dominated by hard clays which are known to adsorb the fluoride ion strongly. The $\mathrm{F}^{-}$ion replaces the $\mathrm{OH}^{-}$ion easily due to their similar ionic radii (Hitchon 1995), thus enhancing chances of presence of high fluoride in water circulating in clay-dominated regions. 

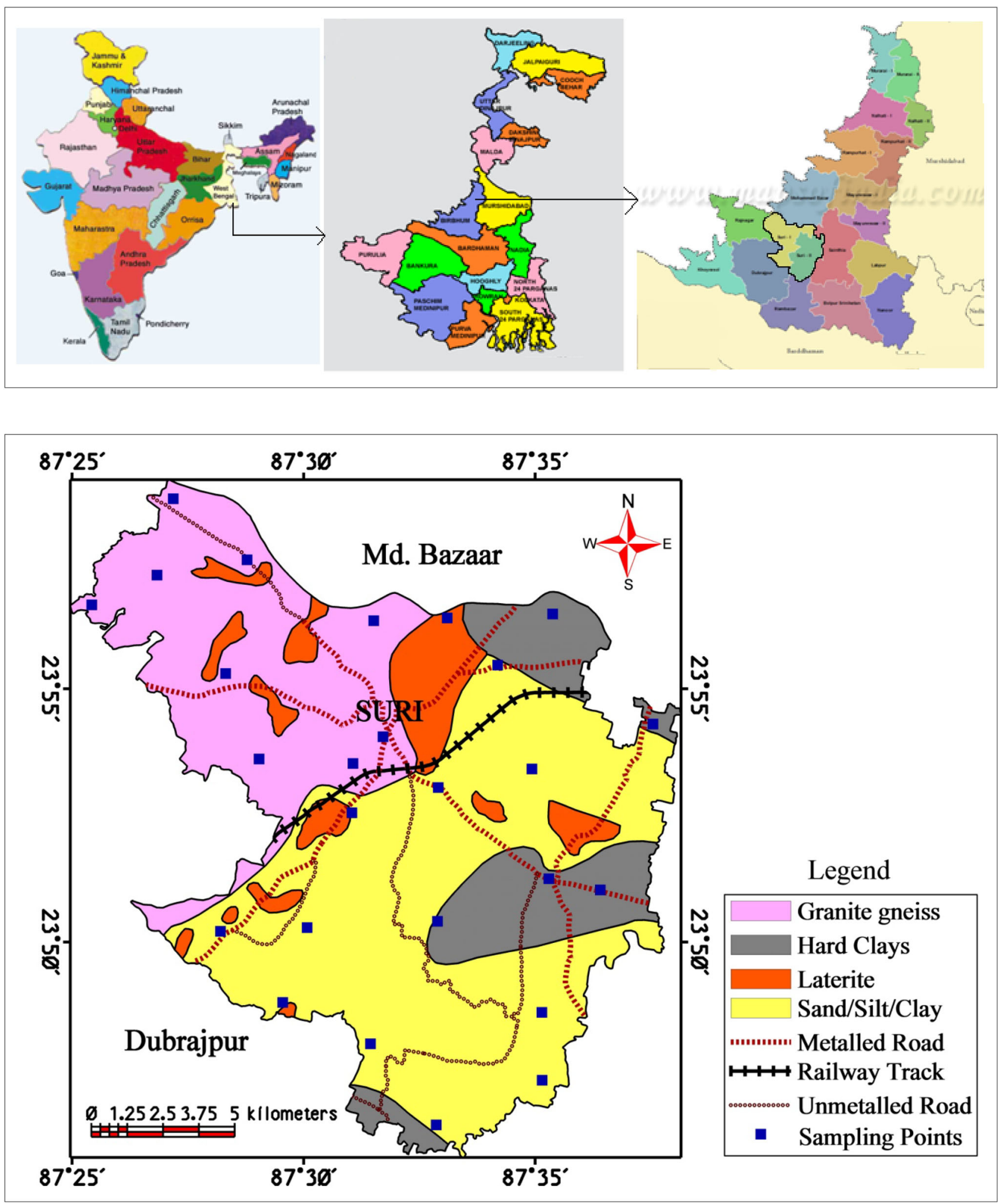

Fig. 1 Map of the study area

Granitic rocks are a typical source of fluoride-rich rocks. They have been reportedly found to contain much higher fluoride than any other rock type. Fluoride content in granitic rocks can range anywhere between 500 and $1400 \mathrm{mg} / \mathrm{kg}$ (Koritnig 1978; Krauskopf and Bird 1995; Brindha and Elango 2011). The dominant fluoride-bearing minerals in 


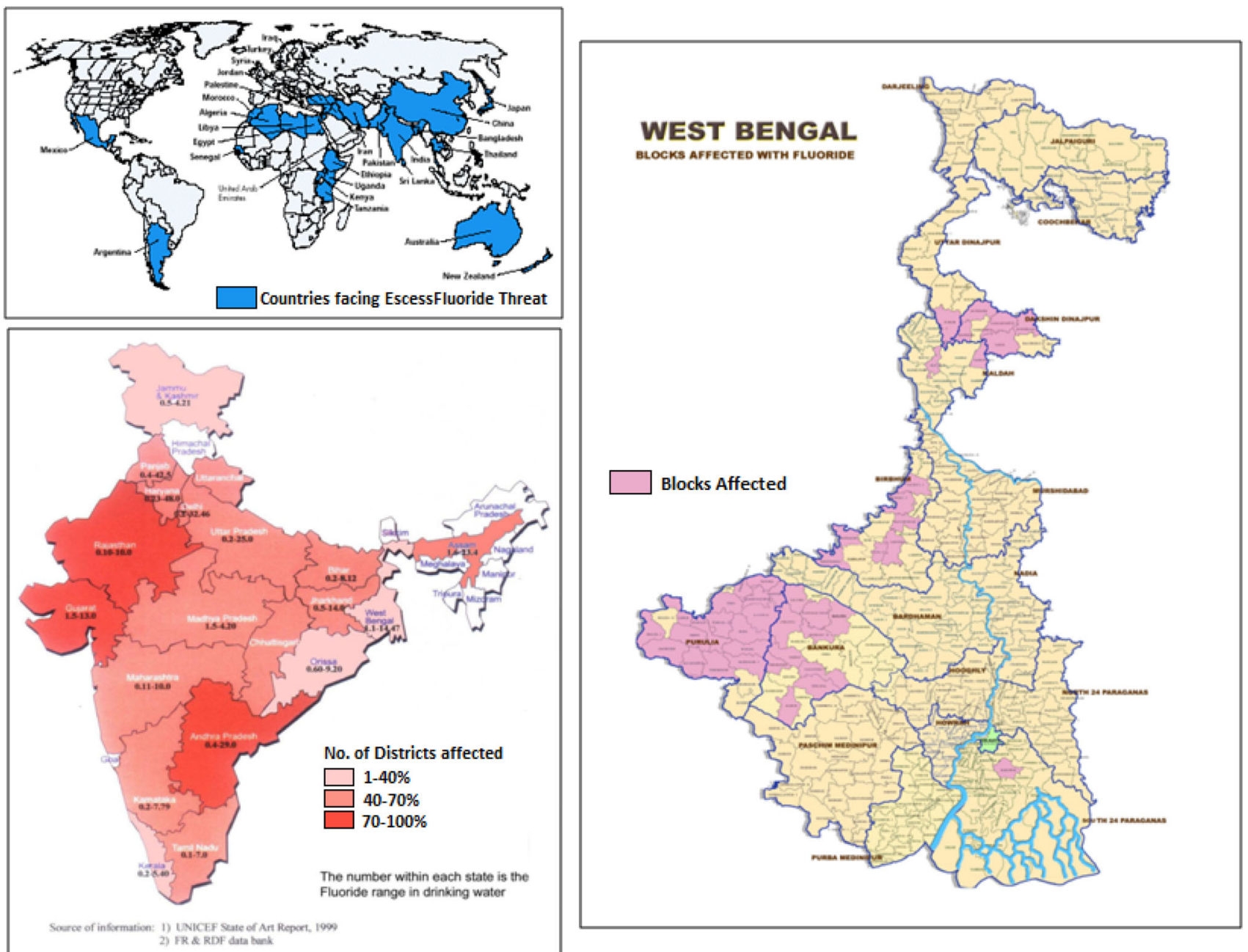

Fig. 2 Distribution pattern of fluoride on a global, national and state scale

these rocks are fluorite $\left[\mathrm{CaF}_{2}\right]$, villiaumite $[\mathrm{NaF}]$, fluoroapatite $\left[\mathrm{Ca}_{5}\left(\mathrm{PO}_{4}\right)_{3} \mathrm{~F}\right]$, biotite $\left[\mathrm{K}(\mathrm{Mg}, \mathrm{Fe})_{2}\left(\mathrm{AlSi}_{2} \mathrm{O}_{10}\right)(\mathrm{F}, \mathrm{OH})_{2}\right]$, etc. Whether or not dissolution and leaching of these various minerals into groundwater are a major source of fluoride content in water can be confirmed when the factors controlling hydrogeochemistry of groundwater are explored. Of the many controlling factors-evaporation, precipitation and rock-water interaction are some of the preliminary factors. Whichever particular factor controls the overall hydrogeochemistry of an area, can be identified with the help of the Gibb's Diagram (Gibbs 1970). In Fig. 4a, b, the Gibbs's diagrams for post- and pre-monsoon sessions have been presented. From the Gibb's diagrams, it can be clearly interpreted that rock-water interaction is a dominant factor affecting the hydrogeochemistry of the study area during post-monsoon as well as pre-monsoon. Hence, dissolution and leaching of fluoride-bearing minerals into groundwater from the rocks lining the aquifers holding groundwater at optimal conditions can be attributed to be a significant source of fluoride ion in groundwater.
The fluorine-bearing minerals in granites and metamorphic rocks: fluorite, apatite, fluorapatite, cryolite, micas and amphiboles (Handa 1975; Pickering 1985; Subba Rao and Devdas 2003; Zhang et al. 2003) undergo dissociation or displacement reactions to release fluoride into water. Of all the above minerals mentioned, fluorite is the most common fluorine-bearing mineral found in granitic terrains (Deshmukh et al. 1995; Shah and Danishwar 2003)—which is a dominant feature in the chosen area of this research. Fluoride concentration in the collected water samples for both sampling sessions obtained through quantitative chemical analysis experiments have been presented in Table 1. To evaluate which particular mineral/minerals of the above-mentioned minerals might be contributing to fluoride levels in groundwater of this area, the use of the geochemical model PHREEQC 3.0.3 was made. The model helps to speciate the quantitative chemical analysis results. Simulations done over the raw quantitative data lead to results presenting phases (major minerals) predicted to be present in water and/or SI of these phases. 
Fig. 3 a Spatial distribution map of $\mathrm{F}^{-}$for post-monsoon. b Spatial distribution map of $\mathrm{F}^{-}$ for pre-monsoon

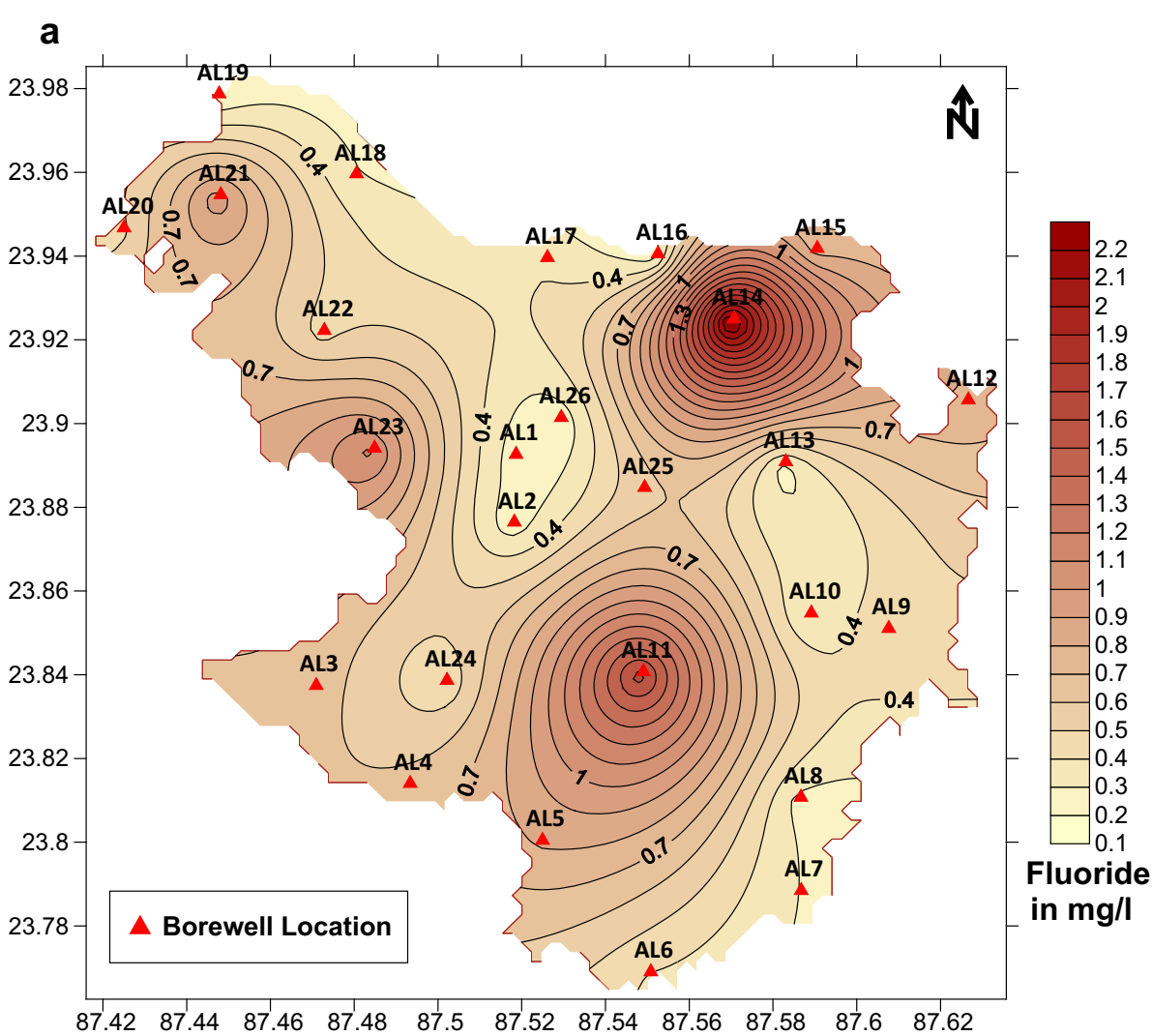

b

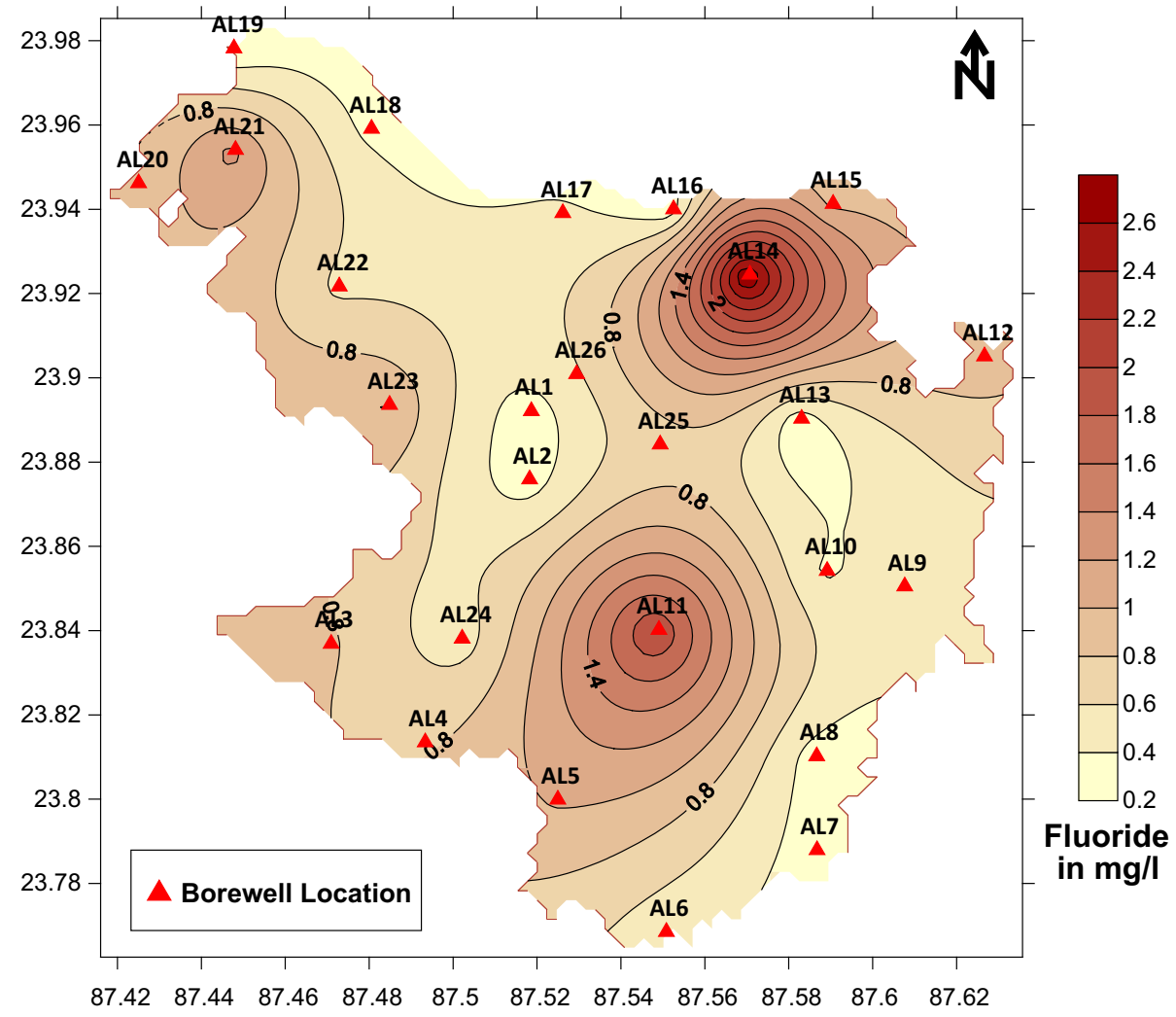


Fig. 4 Gibb's diagrams

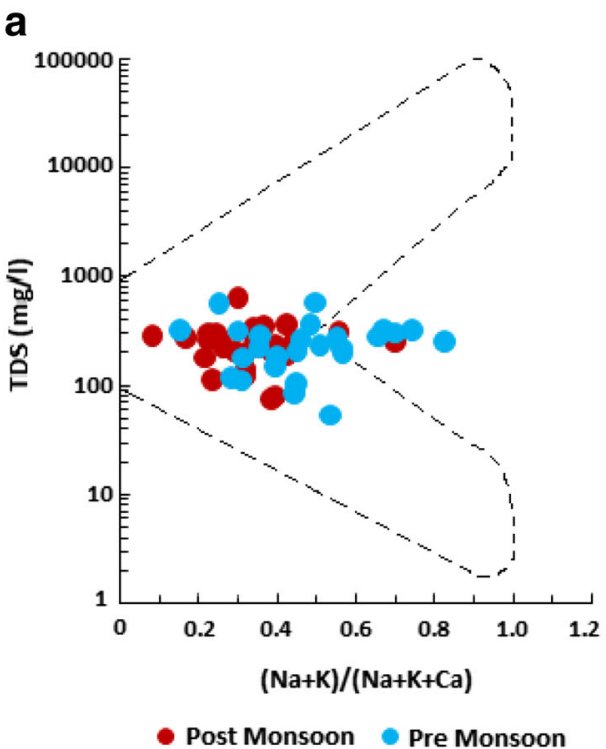

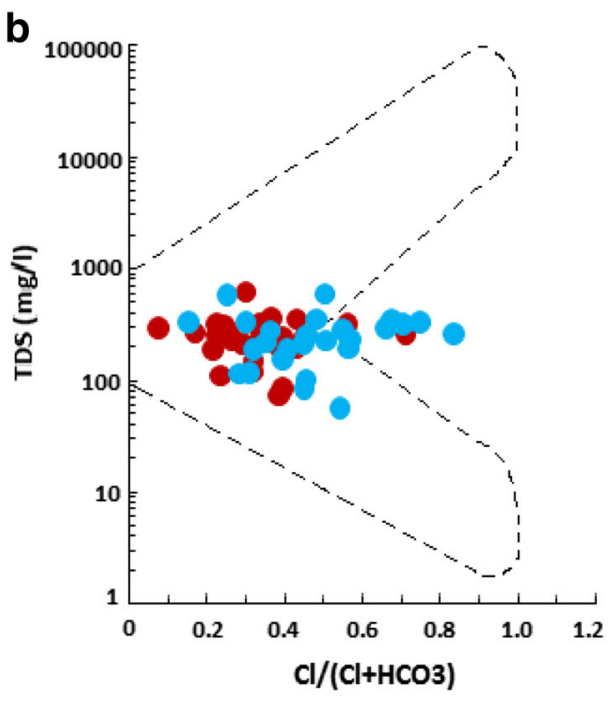

- Post Monsoon Pre Monsoon
Table 1 Quantitative chemical analysis results for fluoride in groundwater

\begin{tabular}{|c|c|c|c|}
\hline \multirow[t]{2}{*}{ Location no. } & \multirow[t]{2}{*}{ Location name } & \multicolumn{2}{|c|}{ Fluoride $\left(\mathrm{F}^{-}\right)$in $\mathrm{mg} / \mathrm{l}$} \\
\hline & & $\begin{array}{l}\text { Post- } \\
\text { monsoon }\end{array}$ & $\begin{array}{l}\text { Pre- } \\
\text { monsoon }\end{array}$ \\
\hline AL1 & Abdarpur & 0.26 & 0.31 \\
\hline AL2 & Singur & 0.25 & 0.29 \\
\hline AL3 & Kochujor Primary School & 0.65 & 0.83 \\
\hline AL4 & Lalmohanpur Primary School & 0.63 & 0.79 \\
\hline AL5 & Bonsonka Primary School & 0.81 & 1.02 \\
\hline AL6 & Talibpur High School & 0.40 & 0.47 \\
\hline AL7 & Kubirpur Primary School & 0.30 & 0.31 \\
\hline AL8 & Abinashpur Hospital (Sultanpur) & 0.27 & 0.31 \\
\hline AL9 & Piasala More & 0.49 & 0.56 \\
\hline AL10 & Purandarpur & 0.29 & 0.38 \\
\hline AL11 & Gangta (Beside Mandir) & 1.66 & 2.02 \\
\hline AL12 & Majhigram & 0.79 & 0.91 \\
\hline AL13 & Bhaganbati Primary School & 0.27 & 0.27 \\
\hline AL14 & Dhalla & 2.38 & 2.84 \\
\hline AL15 & Saktipur Primary School & 0.78 & 0.97 \\
\hline AL16 & Ajaypur & 0.25 & 0.28 \\
\hline AL17 & Joka Primary School & 0.40 & 0.45 \\
\hline AL18 & Khatangadi & 0.31 & 0.35 \\
\hline AL19 & Kendulia & 0.22 & 0.24 \\
\hline AL20 & Lataboni Primary School & 0.47 & 0.83 \\
\hline AL21 & Nabagram Primary School & 0.97 & 1.26 \\
\hline AL22 & Aamgachi Udayan Pathsala & 0.47 & 0.56 \\
\hline AL23 & Gobindopur Unique Club & 1.13 & 1.01 \\
\hline AL24 & Agar & 0.41 & 0.48 \\
\hline AL25 & Ekdala More & 0.56 & 0.71 \\
\hline AL26 & Suri Town & 0.21 & 0.56 \\
\hline
\end{tabular}

The saturation index values obtained from PHREEQC simulations carried out on two sets of data for each sampling session-one where highest value of fluoride has been recorded and another where the lowest value of fluoride has been recorded, have been presented in Table 2.

The common mineral bearing fluoride during both sampling sessions has been found to be fluorite $\left(\mathrm{CaF}_{2}\right)$. Fluoride ion takes relatively long time to leach out into groundwater due to its low solubility. In such conditions, its occurrence is predominantly controlled by free calcium ions $\left(\mathrm{Ca}^{2+}\right)$ sourced into groundwater majorly from the common mineral, calcite $\left(\mathrm{CaCO}_{3}\right)$ (Jacks et al. 2005). The dissociation reactions and solubility products of fluorite (Eqs. 1, 3) and calcite (Eqs. 2, 4) can be demonstrated by the following equations (Handa 1975):

$\mathrm{CaCo}_{3}+\mathrm{H}^{+} \leftrightarrow \mathrm{Ca}^{2+}+\mathrm{HCO}_{3}^{-}$

where the equilibrium constant

$\mathrm{K}_{\text {calcite }}\left(\mathrm{K}_{1}\right)=\left\{\left[\mathrm{Ca}^{2+}\right]\left[\mathrm{HCO}_{3}^{-}\right]\right\} /\left[\mathrm{H}^{+}\right]$.

$\mathrm{CaF}_{2} \leftrightarrow \mathrm{Ca}^{2+}+2 \mathrm{~F}^{-}$,

where the equilibrium constant

$\mathrm{K}_{\text {fluorite }}\left(\mathrm{K}_{2}\right)=\left[\mathrm{Ca}^{2+}\right]\left[\mathrm{F}^{-}\right]^{2}$.

Coupling the above equations, Handa (1975) formulated Eq. 5 as follows:

$\mathrm{CaCO}_{3}(\mathrm{~s})+\mathrm{H}^{+}+2 \mathrm{~F}^{-}=\mathrm{CaF}_{2}(\mathrm{~s})+\mathrm{HCO}_{3}^{-}$.

A ratio of the two equilibrium constants can be presented as:

$\mathrm{K}_{\text {cal-fluor }}\left(\mathrm{K}_{1} / \mathrm{K}_{2}\right)=\left[\mathrm{HCO}_{3}^{-}\right] /\left\{\left[\mathrm{H}^{+}\right]\left[\mathrm{F}^{-}\right]^{2}\right\}$. 
From the above formulations, it can be interpreted that at a homogeneous $\mathrm{pH}$ range (defined by the $\mathrm{H}^{+}$ion concentration), where water is of bicarbonate type, fluoride

Table 2 Saturation index values of fluorite and calcite

\begin{tabular}{|c|c|c|c|c|}
\hline \multirow[t]{2}{*}{ Location no. } & \multicolumn{2}{|c|}{ Post-monsoon } & \multicolumn{2}{|c|}{ Pre-monsoon } \\
\hline & $\mathrm{SI}_{\text {fluorite }}$ & $\mathrm{SI}_{\text {calcite }}$ & $\mathrm{SI}_{\text {fluorite }}$ & $\mathrm{SI}_{\text {calcite }}$ \\
\hline AL1 & -2.77 & -0.01 & -2.96 & -0.97 \\
\hline AL2 & -2.65 & -0.23 & -2.69 & -0.36 \\
\hline AL3 & -1.26 & 1.32 & -1.37 & 0.54 \\
\hline AL4 & -1.73 & 2.12 & -1.77 & 1.23 \\
\hline AL5 & -1.39 & 1.03 & -1.64 & 1.12 \\
\hline AL6 & -1.99 & 1.22 & -2.35 & 0.29 \\
\hline AL7 & -2.49 & 1.82 & -2.52 & 0.39 \\
\hline AL8 & -2.43 & 1.83 & -2.42 & 1.33 \\
\hline AL9 & -2.38 & 2.15 & -2.16 & 0.39 \\
\hline AL10 & -2.03 & 1.2 & -2.16 & 0.45 \\
\hline AL11 & -1.04 & 2.05 & -0.79 & 1.83 \\
\hline AL12 & -1.51 & 1.36 & -1.17 & 1.16 \\
\hline AL13 & -2.13 & 0.99 & -2.16 & 0.54 \\
\hline AL14 & -1.34 & 1.86 & -1.06 & 1.23 \\
\hline AL15 & -1.53 & 0.8 & -1.52 & 1.57 \\
\hline AL16 & -2.52 & 0.6 & -2.48 & 0.38 \\
\hline AL17 & -2.59 & 2.11 & -2.28 & 1.24 \\
\hline AL18 & -2.28 & 1.69 & -1.38 & 1.29 \\
\hline AL19 & -2.79 & 2.35 & -2.51 & 0.49 \\
\hline AL20 & -1.86 & 1.69 & -1.52 & 0.38 \\
\hline AL21 & -1.3 & 0.91 & -1.35 & 0.29 \\
\hline AL22 & -2.04 & 0.67 & -1.95 & 0.2 \\
\hline AL23 & -1.33 & 1.73 & -1.57 & -0.15 \\
\hline AL24 & -2.05 & 2.03 & -2.27 & -0.04 \\
\hline AL25 & -2.07 & 2.32 & -1.89 & 0.57 \\
\hline AL26 & -2.52 & 0.82 & -1.74 & -0.03 \\
\hline
\end{tabular}

a

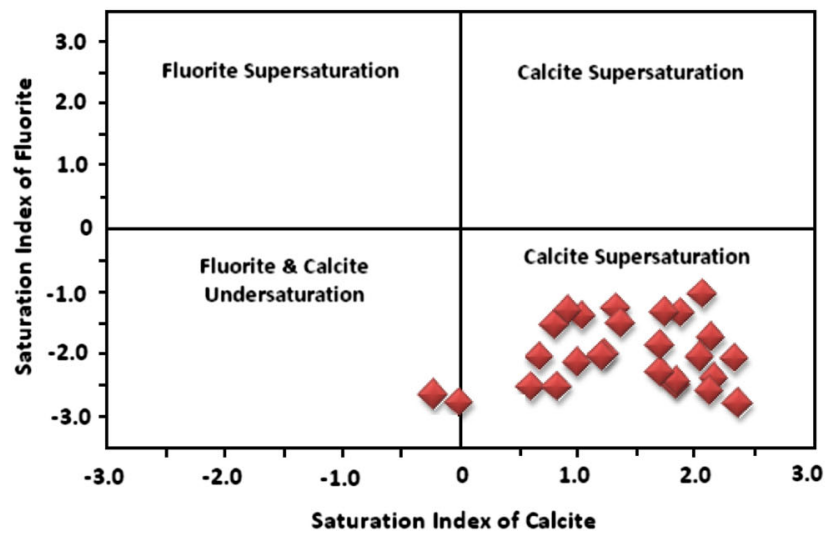

concentration in water tends to rise with a dip in the calcium concentration.

According to the geochemical model used, fluorite has been found to be the dominant fluoride-bearing mineral in groundwater; hence, the saturation indices of fluorite and calcite have been calculated for each sample collected over both the sampling sessions. Figure $5 \mathrm{a}, \mathrm{b}$ below presents the graphical distribution of SI values of fluorite and calcite. Saturation index (S.I.) (Eq. 7) of a chemical compound is calculated using the following standard formula:

S.I. $=\log _{10} Q / K$,

where $Q$ is the ionic activity product of a mineral, in this case-fluorite or calcite; $K$ is the equilibrium constant of the mineral.

The interaction of a mineral with water (precipitation or dissolution of ions into water) can be explained based on its saturation index value (Al-Amry 2009; Dey et al. 2011; Sreedevi et al. 2006). SI values define the following phases:

When SI $>0$, the mineral lies in super-saturated domain (precipitates from the aqueous medium).

When $\mathrm{SI}=0$, the mineral is in equilibrium with the aqueous medium.

When SI $<0$, the mineral lies in under-saturated domain (dissolves into aqueous medium).

According to the SI values, majority of the samples of the study area are under-saturated with respect to fluorite and super-saturated with respect to calcite during both post-monsoon (Fig. 5a) and pre-monsoon (Fig. 5b). Generally, groundwater is under-saturated with respect to fluorite (Handa 1975), but in some cases, they are saturated or over-saturated with respect to both fluorite and calcite (Srinivasa Rao 1997; Smedley et al. 2002; Chae et al. 2007). Cases where both calcite and fluorite saturation occurs in groundwater with high fluoride have also been

b

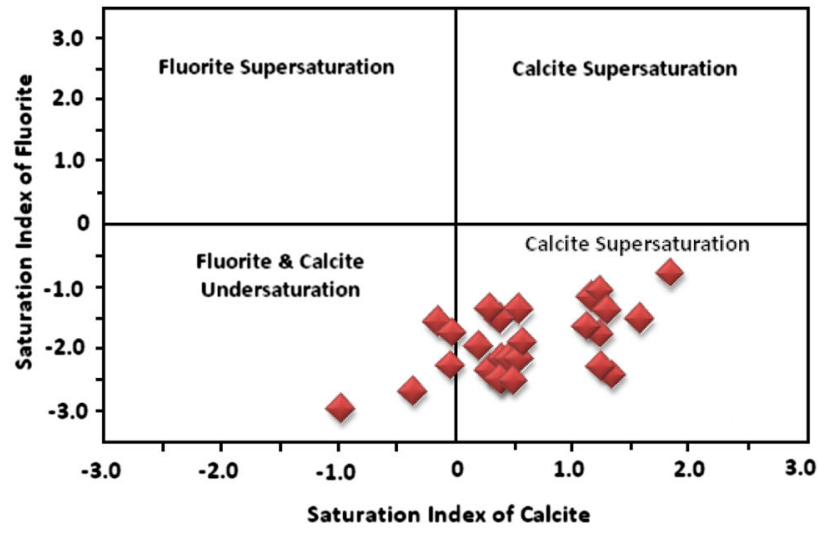

Fig. 5 a Plot of SI fluorite vs. SI calcite (POM). b Plot of SI fluorite vs. SI calcite (PRM) 
Table 3 Chloro-alkaline index (CA1 and CA2) values

\begin{tabular}{|c|c|c|c|c|}
\hline \multirow[t]{2}{*}{ Location no. } & \multicolumn{2}{|c|}{ Post-monsoon } & \multicolumn{2}{|c|}{ Pre-monsoon } \\
\hline & CAI1 & $\mathrm{CAI} 2$ & CAI1 & CAI2 \\
\hline AL1 & 0.43 & 0.12 & 0.062 & 0.032 \\
\hline AL2 & 0.33 & 0.27 & 0.271 & 0.182 \\
\hline AL3 & 0.35 & 0.09 & 0.430 & 0.581 \\
\hline AL4 & -0.57 & -0.03 & -1.901 & -0.234 \\
\hline AL5 & -0.13 & 0.00 & 0.185 & 0.036 \\
\hline AL6 & -2.26 & -0.05 & -3.181 & -0.284 \\
\hline AL7 & 0.36 & 0.03 & -0.998 & -0.224 \\
\hline AL8 & -0.55 & -0.02 & -0.401 & -0.066 \\
\hline AL9 & -1.37 & -0.09 & -1.858 & -0.357 \\
\hline AL10 & 0.85 & 0.17 & 0.831 & 0.624 \\
\hline AL11 & -0.95 & -0.07 & -0.972 & -0.213 \\
\hline AL12 & -1.08 & -0.04 & -0.970 & -0.136 \\
\hline AL13 & -0.08 & -0.01 & 0.791 & 2.388 \\
\hline AL14 & -1.58 & -0.10 & -4.364 & -0.532 \\
\hline AL15 & -0.55 & -0.04 & -0.428 & -0.114 \\
\hline AL16 & -0.10 & -0.01 & -0.018 & -0.004 \\
\hline AL17 & -1.49 & -0.07 & -2.408 & -0.295 \\
\hline AL18 & -0.03 & 0.00 & 0.134 & 0.060 \\
\hline AL19 & -0.13 & -0.02 & 0.273 & 0.220 \\
\hline AL20 & 0.40 & 0.15 & 0.345 & 0.179 \\
\hline AL21 & -0.48 & -0.04 & -0.604 & -0.168 \\
\hline AL22 & -0.04 & 0.00 & 0.250 & 0.086 \\
\hline AL23 & 0.29 & 0.03 & 0.290 & 0.231 \\
\hline AL24 & -0.79 & -0.05 & -0.967 & -0.436 \\
\hline AL25 & -0.97 & -0.03 & -1.406 & -0.123 \\
\hline AL26 & 0.64 & 0.18 & 0.534 & 0.338 \\
\hline
\end{tabular}

reported previously (Brindha and Elango 2011). At a couple of locations, calcite lies in the under-saturated zone during both sampling sessions. If relative increase of fluoride in groundwater is observed even when calcite mineral lies in the under-saturated domain, it might be due to the ion exchange phenomenon [where calcium $(\mathrm{Ca})$ or magnesium $(\mathrm{Mg})$ in groundwater is exchanged with sodium (Na) or potassium $(\mathrm{K})$ in the aquifer material]. Chloroalkaline indices (CA1 and CA2, defined by Eqs. 8, 9), commonly known as indices of base exchange (Schoeller 1965, 1977), are used as indicators to determine whether ion exchange or reverse ion exchange takes place in groundwater.

$$
\begin{aligned}
\mathrm{CA} 1= & {\left[\mathrm{Cl}^{-}-(\mathrm{Na}+\mathrm{K})\right] / \mathrm{Cl}^{-}, } \\
\mathrm{CA} 2= & {\left[\mathrm{Cl}^{-}-(\mathrm{Na}+\mathrm{K})\right] / } \\
& \left(\mathrm{SO}_{4}^{2-}+\mathrm{HCO}_{3}^{-}+\mathrm{CO}_{3}^{2-}+\mathrm{NO}_{3}^{-}\right),
\end{aligned}
$$

where concentrations of all ions have been expressed in meq/l.
When there is an exchange between $\mathrm{Na}$ and/or $\mathrm{K}$ in groundwater with $\mathrm{Mg}$ and/or $\mathrm{Ca}$ in the aquifer material, both of the indices are positive, indicating reverse ion exchange. When the reverse of this process occurs, the indices have a negative value, indicating ion exchange (Rajmohan and Elango 2004; Arveti et al. 2011). In Table 3 below, the chloro-alkaline index (CA1 and CA2) values of both postmonsoon and pre-monsoon sessions have been presented.

Geochemistry of fluoride in groundwater can also be assessed by correlating its concentration in water to the type of the water it is in association with (Apambire et al. 1997). Delineation of "Water types" can be carried out using the Piper's trilinear diagram. Sodium bicarbonate type waters are typical of high fluoride waters (Handa 1975; Srinivasa Rao 1997; Chae et al. 2007). Correlation analysis studies carried out in such cases have shown that fluoride, in most cases, bears a positive correlation with both sodium and bicarbonate and a negative correlation with calcium; which particular trend has also been observed in groundwaters of the present study area. To relate concentration of fluoride in groundwater to the groundwater type, the samples in the quantitative analysis data sets for both post-monsoon and pre-monsoon sessions were divided into three categories according to their corresponding fluoride levels. The limits of the fluoride values considered for each category were as follows:

1. Less than $0.6 \mathrm{mg} / \mathrm{l}$

2. $0.6-1.5 \mathrm{mg} / \mathrm{l}$

3. Greater than $1.5 \mathrm{mg} / \mathrm{l}$

For each class, a Piper trilinear diagram was plotted to interpret the overall water type and a pie diagram to present the ratio of $\mathrm{Na}: \mathrm{Ca}$ (sodium:calcium) ratio which increases gradually as fluoride concentration in water increases (Beg et al. 2011).

Figures 6a, b, c and 7 present the Piper diagrams and pie diagrams respectively for the three fluoride data classes for post-monsoon session.

The Piper trilinear diagrams of the post-monsoon session depict that water with high fluoride is of $\mathrm{Na}-\mathrm{HCO}_{3}$ (sodium bicarbonate) type, whereas water containing low quantities of fluoride is mostly of $\mathrm{Ca}-\mathrm{Mg}-\mathrm{HCO}_{3}$ (mixed) type. The three corresponding pie diagrams present the gradual rise in $\mathrm{Na}: \mathrm{Ca}$ distribution with rise in fluoride concentration.

Figures 8a, b, c and 9 present the Piper diagrams and pie diagrams respectively for the three fluoride data classes for pre-monsoon session.

During the pre-monsoon session, water containing low quantities of fluoride are $\mathrm{Ca}-\mathrm{Mg}-\mathrm{HCO}_{3}, \mathrm{Ca}-\mathrm{Mg}-\mathrm{Cl}-\mathrm{SO}_{4}$ and $\mathrm{Ca}-\mathrm{Mg}-\mathrm{SO}_{4}$ (mixed) types, whereas water with high fluoride is $\mathrm{Na}-\mathrm{HCO}_{3}$ (sodium bicarbonate) type. The corresponding pie diagrams present the rise in $\mathrm{Na}: \mathrm{Ca}$ ratio with increase in fluoride concentration. 

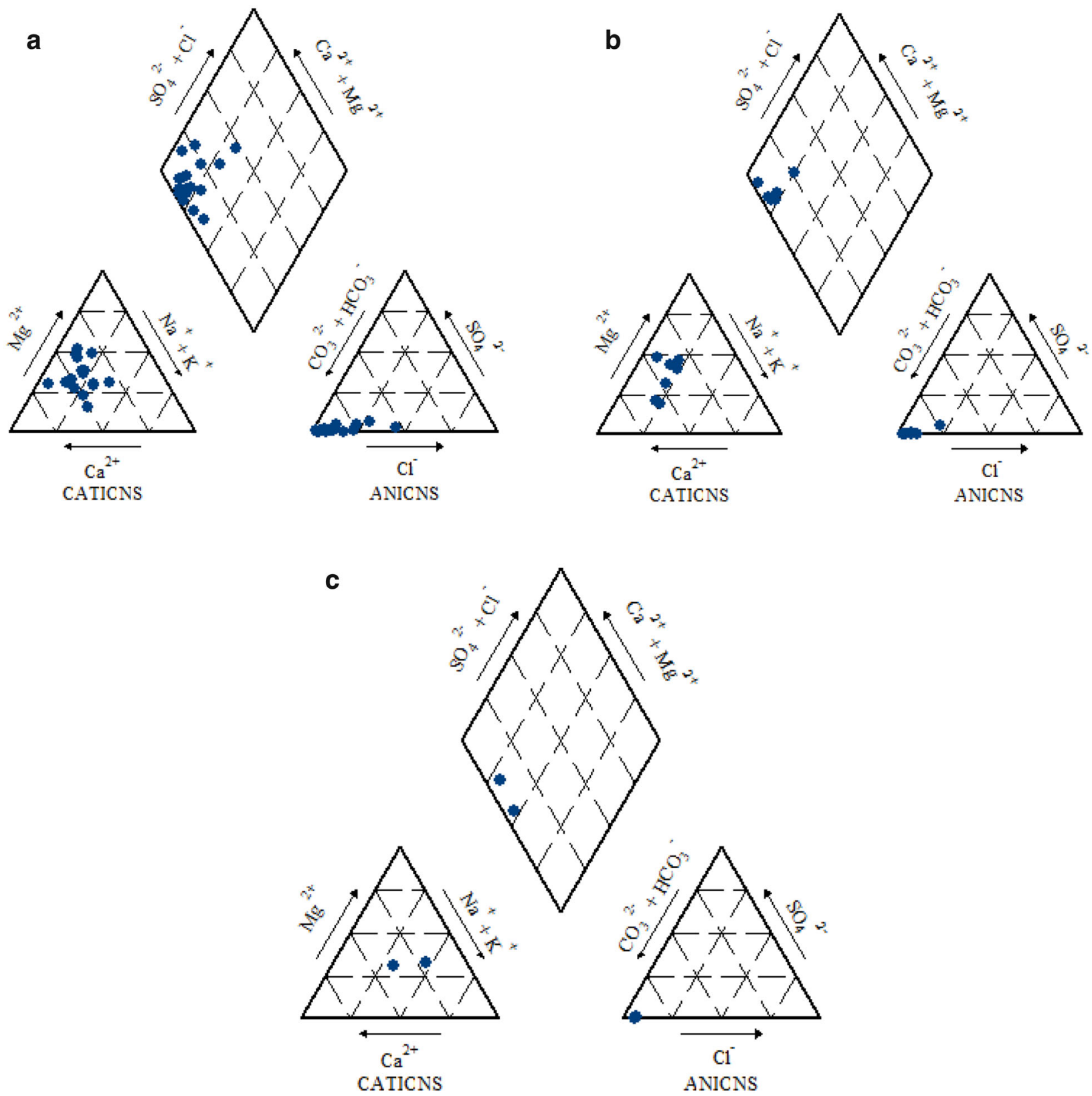

Fig. 6 a Piper diagram for $\mathrm{F}^{-}<0.6 \mathrm{mg} / \mathrm{I}(\mathrm{POM})$. b Piper diagram for $\mathrm{F}^{-} 0.6-1.5 \mathrm{mg} / \mathrm{I}(\mathrm{POM})$. c Piper diagram for $\mathrm{F}^{-}>1.5 \mathrm{mg} / \mathrm{I}(\mathrm{POM})$

Fig. 7 Pie diagram presenting $\mathrm{Na}: \mathrm{Ca}$ ratio for $\mathrm{POM}$ session

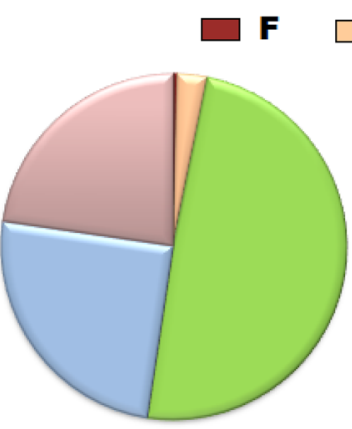

$\mathrm{Na}: \mathrm{Ca}=\mathbf{0 . 5 0}$

$\mathbf{F}^{-}<0.6 \mathrm{mg} / \mathrm{l}$

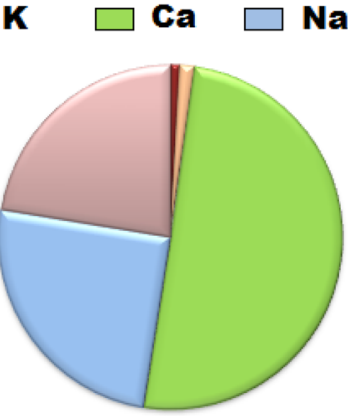

$\mathrm{Na}: \mathrm{Ca}=\mathbf{0 . 5 0}$

$F^{-} 0.6$ - $1.5 \mathrm{mg} / \mathrm{l}$ $\square \mathbf{M g}$

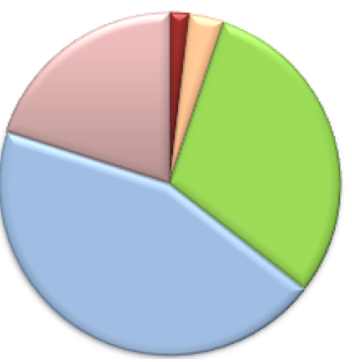

$\mathrm{Na}: \mathrm{Ca}=1.46$

$F^{-}>1.5 \mathrm{mg} / \mathrm{l}$ 

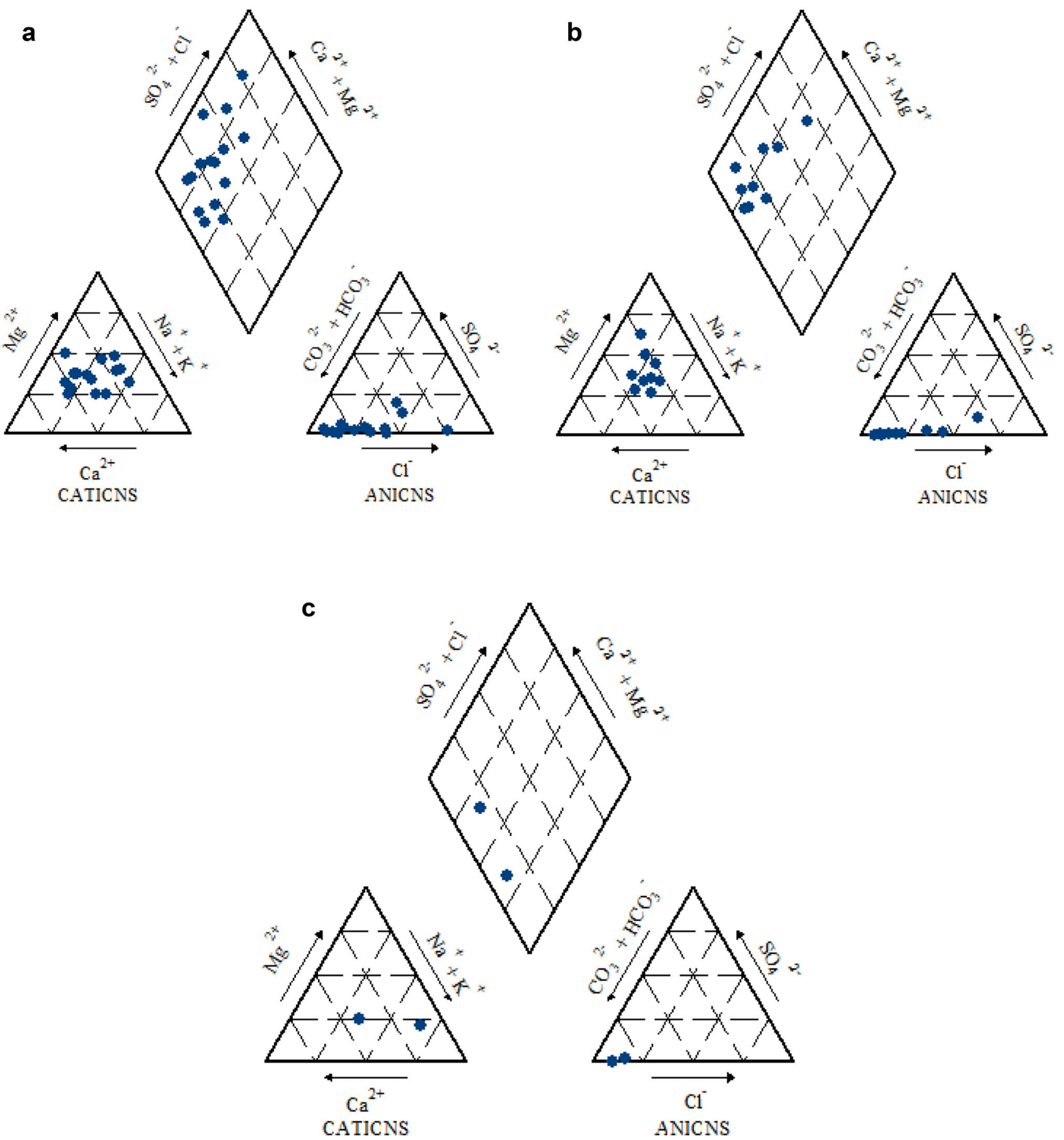

Fig. 8 a Piper diagram for $\mathrm{F}^{-}<0.6 \mathrm{mg} / \mathrm{I}(\mathrm{PRM})$. b Piper diagram for $\mathrm{F}^{-} 0.6-1.5 \mathrm{mg} / \mathrm{I}(\mathrm{PRM})$. c Piper diagram for $\mathrm{F}^{-}>1.5 \mathrm{mg} / \mathrm{I}(\mathrm{PRM})$

\section{Conclusions}

Fluoride occurrence in the study area has been found to be a localized phenomenon as excess fluoride $(>1.5 \mathrm{mg} / \mathrm{l})$ was reported in two out of 26 locations. Major parts of the study area are dominated by granite gneisses and recent layers of alluvium as evident from lithology map of the area. Pockets of hard clays are also common on the eastern parts of the blocks. Average fluoride concentration in groundwater rises during pre-monsoon in comparison with postmonsoon. In between these sampling sessions, aquifer reserves are not recharged because monsoon precedes both sampling sessions. Hence, there is very less chance of increase in fluoride concentration of groundwater due to any other source besides the aquifer materials. Association of fluoride-bearing minerals like apatite, fluorapatite and 
Fig. 9 Pie diagram presenting $\mathrm{Na}$ Ca ratio for PRM session

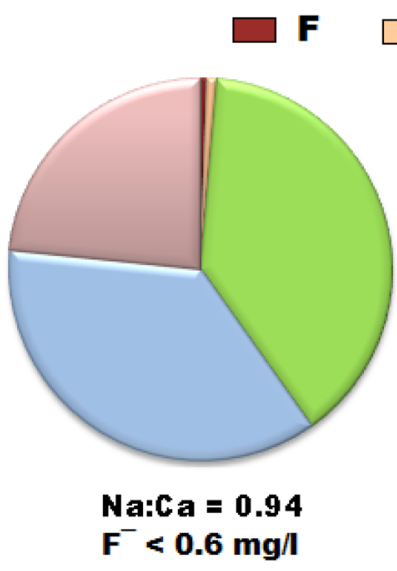

Na:Ca $=0.94$
$F^{-}<0.6 \mathrm{mg} / \mathrm{l}$

fluorite with the lithology type the present study area bears, is quite common, and geochemical modeling studies have revealed that fluorite $\left(\mathrm{CaF}_{2}\right)$ is, indeed, present as a significant fluoride-bearing mineral in the groundwaters of this study area. Calcite or $\mathrm{CaCO}_{3}$ is one of the most common minerals with which fluorite remains associated, and saturation index calculations have revealed that the calcite-fluorite geochemistry is the dominant factor controlling fluoride concentration in this area during both postand pre-monsoon. High fluoride waters have also been found to be of 'bicarbonate' type showing increase of sodium in water with decrease of calcium.

Acknowledgments The author (S. Das) gratefully acknowledges the financial support from UGC, New Delhi and Jadavpur University also for providing the fellowship to her under UGC Meritorious Scheme. The other author (S. K. Nag) is thankful to Jadavpur University for providing financial assistance in conducting the field work related to this work.

Open Access This article is distributed under the terms of the Creative Commons Attribution 4.0 International License (http:// creativecommons.org/licenses/by/4.0/), which permits unrestricted use, distribution, and reproduction in any medium, provided you give appropriate credit to the original author(s) and the source, provide a link to the Creative Commons license, and indicate if changes were made.

\section{References}

Agarwal V, Vaish AK, Vaish P (1997) Groundwater quality: focus on fluoride and fluorosis in Rajasthan. Curr Sci 73(9):743-764

Al-amry AS (2009) Hydrogeochemistry and origin of fluoride in groundwater of Hidhran \& Alburayhi Basin, northwest Taiz City, Yemen. Delta J Sci 33:10-20

Apambire WB, Boyle DR, Michael FA (1997) Geochemistry, genesis, and health implications of fluoriferous groundwaters in the upper regions of Ghana. Environ Geol 33(1):13-24

APHA (American Public Health Association) (1995) Standard Methods for Examination of Water and Waste Water. American Public Health Association, American Water Works Association and Water Pollution Control Federation, Washington DC, USA
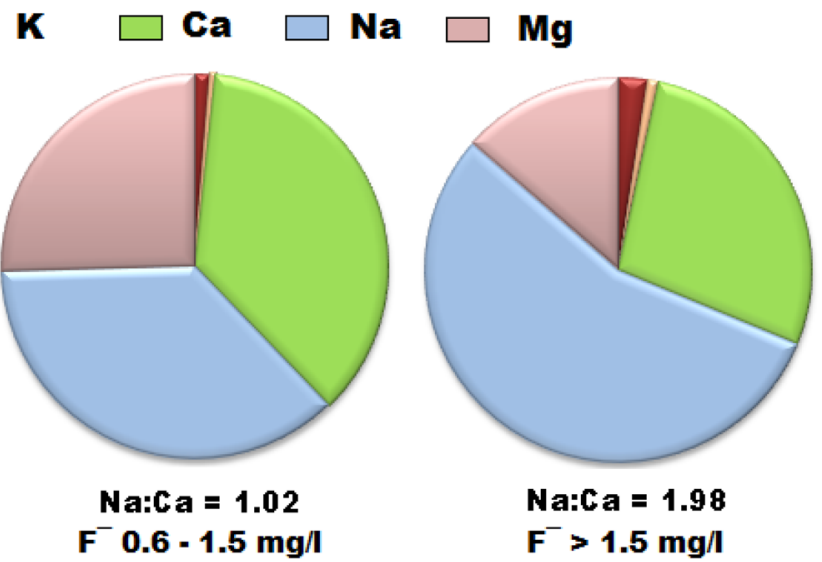

Arveti N, Sarma MRS, Aitkenhead-Peterson J, Sunil K (2011) Fluoride incidence in groundwater: a case study in Talupula, Andhra Pradesh, India. Environ Monit Assess 172:427-443

Beg MK, Srivastava SK, Carranza EJM, de Smeth JB (2011) High fluoride incidence in groundwater and its potential health effects in parts of Raigarh District, Chhattisgarh, India. Curr Sci 100(5):750-754

Boyle DR, Chagnon M (1995) An incidence of skeletal fluorosis associated with groundwaters of the Maritime Carboniferous Basin, Gaspé Region, Quebec, Canada. Environ Geochem Health 17:5-12

Brindha K, Elango L (2011) Fluoride in groundwater: causes, implications and mitigation measures. In: Monroy SD (ed) Fluoride properties, applications and environmental management. Nova Science Publisher, Huntington, New York, US, pp 111-136

Brunt R, Vasak L, Griffioen J (2004) Fluoride in groundwater: probability of occurrence of excessive concentration on global scale. International groundwater resources assessment centre report (IGRAC), Report nr.SP 2004-2012. IGRAC, Utrecht, p 9

Chae GY, Seong TM, Bernard K, Kyoung-Ho K, Seong-Yong K (2007) Fluorine geochemistry in bedrock groundwater of South Korea. Sci Total Environ 385(1-3):272-283

Choubisa SL, Sompura K, Bhatta SK, Choubisa DK, Pandya H, Joshi SC, Choubisa L (1996) Prevalence of fluorosis in some villages of Dungarpur district of Rajasthan. Ind J Environ Health 38:119-126

Deshmukh AN, Valadaskar PM, Malpe DB (1995) Fluoride in environment: a review, Gondwana. Geol Mag 9:1-19

Dey RK, Swain SK, Mishra S, Sharma P, Patnaik T, Singh VK, Dehury BN, Jha U, Patel RK (2011) Hydrogeochemical processes controlling the high fluoride concentration in groundwater: a case study at the Boden block area, Orissa. Environ Monit Assess, India

Edmunds WM, Smedley P (2006) Fluoride in natural waters. In: Selinus O (ed) Essentials of Medical Geology. Elsevier Academic Press, London, pp 301-329

FRRDF (1999) State of the Art Report on the Extent of Fluoride in Drinking Water and the Resulting Endemicity in India; Fluorosis Research and Rural Development Foundation; Scientific and technical information compiled for UNICEF, New Delhi

Gibbs RJ (1970) Mechanisms controlling world's water chemistry. Science 170:1088-1090

Handa BK (1975) Geochemistry and genesis of fluoride containing groundwater in India. Groundwater 13:275-281

Hitchon B (1995) Fluorine in formation water, Alberta basin, Canada. Appl Geochem 10:357-367

Hussain I, Arif M, Hussain J (2011) Fluoride contamination in drinking water in rural habitations of Central Rajasthan. Environ Monit Assess, India 
IPCS (2002) Fluorides. Geneva, World Health Organization. Int Program Chem Saf Environ Health Criteria 22(7):38

Jacks G, Bhattacharyya P, Chaudhary V, Singh KP (2005) Controls on the genesis of high-fluoride groundwaters in India. Appl Geochem 20:221-228

Koritnig S (1978) Fluorine. In: Wedepohl KH (ed) Handbook of geochemistry, vol II/1. Springer, Berlin, p 9C1-B9O3

Krauskopf KB, Bird DK (1995) An introduction to geochemistry. McGraw-Hill Int, Singapore 647

Mangla B (1991) India's dentists squeeze fluoride warnings off tubes. New Sci 131:16

Pickering WF (1985) The mobility of soluble fluoride in soil. Environ Pollut 9:281-308

Piper AM (1944) A graphic procedure in the geochemical interpretation of water analyses. Trans Am Geophys Union 25:914-928

Rajmohan N, Elango L (2004) Identification and evolution of hydrogeochemical processes in the groundwater environment in area of the Palar and Cheyyar River Basins, South India. Environ Geol 46:47-61

Schoeller H (1965) Qualitative evaluation of ground water resources. In: Methods and techniques of ground-water investigation and development. Water Resources Series No. 33, UNESCO, paris, pp 44-52

Schoeller H (1977) Geochemistry of groundwater. In: Brown RH, Konoplyantsev AA, Ineson J, Kovalevsky VS (eds) Groundwater studies-an international guide for research and practice. UNESCO, Paris, pp 1-18

Shah MT, Danishwar S (2003) Potential fluoride concentration in drinking water of Naranji area, North frontier province, Pakistan. Environ Geochem Health 25:475-481

Short HE, Mc Robert GR, Bernard TW, Mannadinayar AS (1937) Endemic fluorosis in the Madras Presidency. Indian J Med Res 25:553-561

Smedley PL, Nicolli HB, Macdonald DMJ, Barros AJ, Tullio JO (2002) Hydrogeochemistry of arsenic and other inorganic constituents in groundwaters from La Pampa, Argentina. Appl Geochem 17:259-284
Sreedevi PD, Ahmed S, Made B, Ledoux E, Gandolfi JM (2006) Association of hydrogeological factors in temporal variations of fluoride concentration in a crystalline aquifer in India. Environ Geol 50:1-11

Srinivasa Rao N (1997) The occurrence and behaviour of fluoride in the groundwater of the Lower Vamsadhara River basin, India. Hydrol Sci 42(6):877-892

Subba Rao N, Devdas DJ (2003) Fluoride incidence in groundwater in area of Peninsula India. Environ Geol 45:243-251

UNICEF (1999a) Fluoride in water: an overview. Waterfront-A UNICEF Publication on Water, Environment, Sanitation and Hygiene, Issue 13, December 1999

UNICEF (1999b) State of the art report on the extent of fluoride in drinking water and the resulting endemicity in India, Fluorosis Research and Rural Development Foundation for UNICEF, New Delhi

WHO (2006) Fluoride in Drinking Water. World Health Organization, London

WHO (2011) Guideline for drinking water quality, 4th edn. World Health Organization, Geneva

Yadav JP, Lata S (2004) Fluoride levels in drinking water sources in rural area of block Jhajjar, district Jhajjar, Haryana. J Water Works Assoc 36(2):131-136

Yadav S, Khan TI, Gupta S, Gupta AB, Yadava RN (1999) Fluorosis in India with special reference to Rajasthan. In: Proceedings of the international conference on water, environment, energy, socioeconomics and health engineering (WEESHE), Seoul National University. 18-21st October 3-10

Yadav JP, Lata S, Kataria SK, Kumar S (2009) Fluoride distribution in groundwater and survey of dental fluorosis among school children in the villages of the Jhajjar District of Haryana, India. Environ Geochem Health 31:431-438

Zhang B, Hong M, Zhao, Lin X, Dong J (2003) Distribution and risk assessment of fluoride in drinking water in the western plain region of Jilin province, China. Environ Geochem Health $25: 421-431$ 